\title{
Perancangan Aplikasi POK (Permintaan Order Kerja) Berbasis Web Pada PT. Pupuk Iskandar Muda
}

\author{
Muhammad Hermansyah, Rahmad Bahri, Rahmat Maulana, M Riyogi Alfitra \\ Program Studi Teknik Informatika, Fakultas Teknik, Universitas Samudra, Langsa Jln. Meurandeh, Kota Langsa, 24410, Indonesia
}

\section{KEYWORDS}

POK, Framework, CodeIgniter, Bootstrap, Web

\section{CORRESPONDENCE \\ E-mail: moehammadhermansyah@gmail.com}

rahmad.bahri@yahoo.co.id

rahmatmaulana012@gmail.com

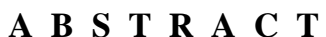

Aplikasi POK (Permintaan Order Kerja) merupakan aplikasi yang digunakan untuk melaporkan suatu permasalahan berupa kerusakan pada suatu benda atau alat pada PT. Pupuk Iskandar Muda. Aplikasi ini dirancang menggunakan framework PHP yaitu CodeIgniter dan Bootstrap. CodeIgniter merupakan framework PHP yang dibuat berdasarkan kaidah MVC (Model-ViewController), sedangkan Bootstrap merupakan sebuah framework css yang memudahkan pengembang untuk membangun website yang menarik dan responsif. Pegawai PT. Pupuk Iskandar Muda dapat menggunakan aplikasi ini dengan menginputkan keluhan (open ticket) berupa teks diwaktu kapan saja dan dimana saja. Hal ini dikarenakan aplikasi POK sudah berbasis online. Setelah ticket dikirim melalui aplikasi, pihak admin akan memeriksa tempat atau departemen yang peralatannya mengalami kerusakan. Pada sistem ini terdapat data karyawan, data departemen, data pengajuan POK, dan laporan pengajuan POK, sehingga dengan adanya Aplikasi Permintaan Order Kerja ini, dapat membantu mempermudah proses pelaporan kerusakan alat.

\section{PENDAHULUAN}

Seiring dengan perkembangan teknologi yang begitu pesat, sistem informasi yang berbasis web dimanfaatkan sebagai sarana peningkatan informasi. Pemanfaatan tersebut akan mempermudah suatu pekerjaan seperti halnya pengolahan data lebih cepat, keputusan yang akan diambil lebih tepat, menghemat waktu dan biaya. Selain itu, sistem informasi berbasis web juga dapat menjadi sarana promosi yang efesien dan sumber informasi yang dapat diakses oleh pengguna internet yang semakin lama semakin luas serta dapat mengembangkan inovasi-inovasi dalam dunia teknologi informasi. Teknologi informasi saat ini sering digunakan untuk menyusun data, mengolah data, mengambil keputusan dan memanipulasi data dalam berbagai cara dengan tujuan menghasilkan informasi yang berkualitas seperti informasi yang relavan, akurat dan tepat waktu, sehingga mudah dimanfaatkan untuk keperluan pribadi, pendidikan, bisnis, dan pemerintahan [1]. Penggunaan teknologi informasi untuk mengolah data menjadi informasi yang akurat dan relevan, dapat digunakan dengan mudah karena sudah berbasis sistem informasi. Hal ini juga telah banyak diterapkan pada perusahaanperusahaan negara seperti PT. Pupuk Iskandar Muda.

PT. Pupuk Iskandar Muda (PIM) merupakan salah satu perusahaan Badan Usaha Milik Negara (BUMN) yang bergerak dalam bidang industri kimia khususnya memproduksi pupuk urea dan ammonia. PT. Pupuk Iskandar Muda mempunyai beberapa Departemen yaitu Departemen Diklat, Departemen Humas, Departemen Umum, Departemen Keamanan, Departemen Pengembangan Sumber Daya Manusia, Departemen Keuangan, Departemen Pemasaran, Departemen Produksi, dan Departemen Teknologi Informasi dan Komunikasi. Untuk peningkatan efektivitas dan efisiensi pengolahan yang bermuara kepada percepatan pencapaian produktivitas dan sasaran perusahaan, PT. Pupuk Iskandar Muda telah membangun suatu infrastruktur jaringan komunikasi data berdasarkan pada teknologi jaringan komunikasi dan komputer yang mampu mendistribusi data atau informasi dengan cepat dan akurat antar unit kerja lingkungan PT. Pupuk Iskandar Muda.

Pendistribusian data atau informasi pada lingkungan unit kerja PT. Pupuk Iskandar Muda sebagian sudah menggunakan sistem informasi. Namun, pada proses Permintaan Order Kerja (POK) masih ditemukan permasalahan. Selama ini proses Permintaan Order Kerja masih dilakukan secara manual, sehingga sering terdapat permasalahan-permasalahan dalam kegiatan operasionalnya. Permasalahan-permasalahan tersebut seperti keterlambatan pemberitahuan dan laporan kerusakan pada alat. Oleh karena itu, untuk mempermudah para pekerja dalam mendapatkan informasi tentang kerusakan alat dan melakukan proses perbaikan alat, diharapkan dapat dibuat sebuah sistem informasi aplikasi Permintaan Order Kerja (POK) secara online. 
Para pegawai kerja tidak lagi harus melaporkan kerusakan alat secara manual dan mengecek alat jika sudah diperbaiki.

\section{METODOLOGI PENELITIAN}

Aplikasi POK (Permintaan Order Kerja) merupakan sebuah aplikasi yang berguna untuk melaporkan suatu permasalahan berupa kerusakan pada suatu benda atau alat pada PT. Pupuk Iskandar Muda. Aplikasi ini dirancang menggunakan framework PHP yaitu CodeIgniter dan Bootstrap. CodeIgniter merupakan framework PHP yang dibuat berdasarkan kaidah MVC (ModelView-Controller), sedangkan Bootstrap merupakan sebuah framework css yang memudahkan pengembang untuk membangun website yang menarik dan responsif. Pegawai PT. Pupuk Iskandar Muda dapat menggunakan aplikasi ini dengan menginputkan keluhan (open ticket) berupa teks diwaktu kapan saja dan dimana saja. Hal ini dikarenakan aplikasi POK sudah berbasis online. Setelah ticket dikirim melalui aplikasi, pihak admin akan memeriksa tempat atau departemen yang peralatannya mengalami kerusakan

\section{Perancangan Sistem}

\section{Diagram Konteks}

Diagram konteks merupakan suatu model yang menjelaskan proses transformasi data secara umum, terdiri dari masukan (input), proses, dan keluaran (output) sistem [5]. Diagram konteks ini menjelaskan secara garis besar tentang masukan (input), proses dan keluaran (output) yang dihasilkan dari sistem yang akan dirancang. Adapun diagram konteks yang di usulkan adalah sebagai berikut:

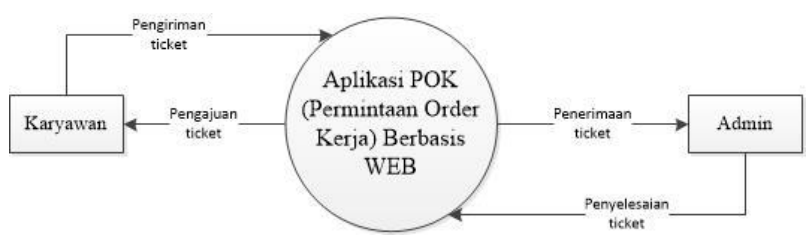

Gambar 1 Diagram Konteks

Pada Gambar 2.1 menjelaskan tentang Aplikasi POK digunakan oleh karyawan dengan melakukan login terlebih dahulu untuk pengajuan ticket, kemudian karyawan melakukan pengiriman ticket ke admin melalui aplikasi. Data ticket yang telah dikirimkan ke Admin akan diproses selanjutnya untuk melakukan perbaikan apa saja yang mengalami kerusakan pada departemen tempat karyawan bekerja. Setelah melakukan perbaikan, admin akan memberitahukan kepada karyawan melalui aplikasi bahwa ticket telah diselesaikan.

\section{Data Flow Diagram (DFD)}

Data Flow Diagram merupakan diagram yang menggambarkan aliran data dalam sistem untuk membangun sistem secara terstruktur.

\section{DFD Level 1}

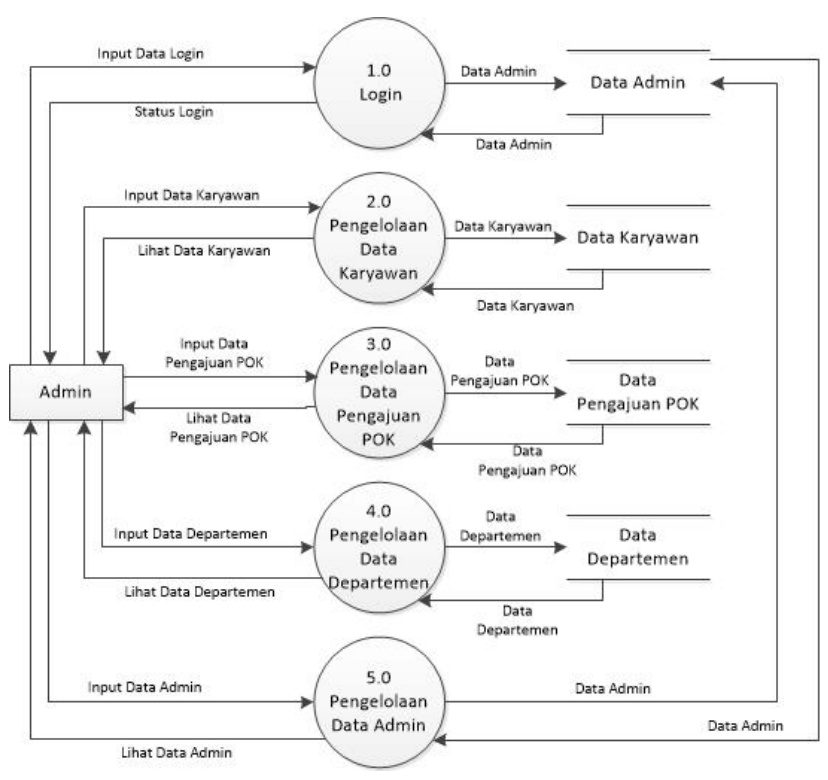

Gambar 2 DFD Level 1

Pada Gambar 2 terdapat 6 proses inti dari pada DFD Level 1, yaitu:

Login

Proses ini merupakan proses login yang digunakan oleh admin agar dapat masuk kedalam sistem yang akan digunakan.

Menginput Master Data Karyawan

Pada proses ini admin melakukan penginputan data karyawan, dan melihat data karyawan.

Menginput Master Data Pengajuan POK

Pada proses ini admin melakukan penginputan master data pengajuan POK, dan melihat data pengajuan POK.

Menginput Master Data Departemen

Pada proses ini admin melakukan penginputan master data departemen, dan melihat data departemen.

Mengelola Data Admin

Pada proses ini admin dapat merubah password lama menjadi password baru serta menambahkan admin/staff baru.

\section{DFD Level 2 Proses 1}

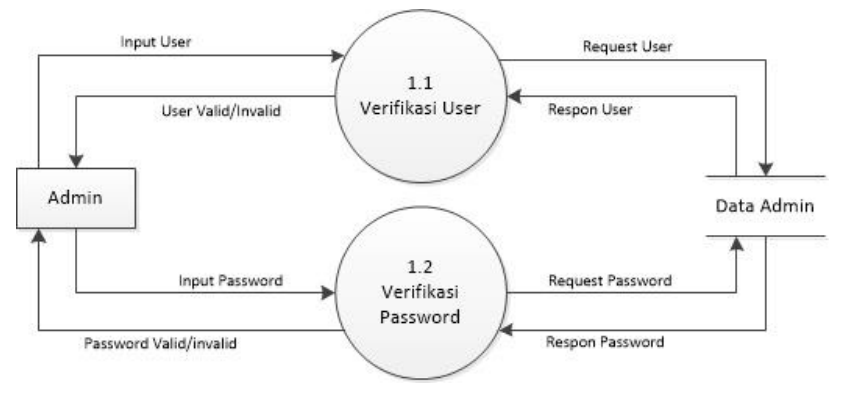

Gambar 3 DFD Level 2 Proses 1

Pada Gambar 3 di atas adalah detail dari pengelolaan admin, yaitu admin harus melakukan login terlebih dahulu untuk dapat menggunakan sistem informasi. Proses login diperlukan untuk mewaspadai manipulasi data oleh oknum yang bukan admin.

\section{DFD Level 2 Proses 2}




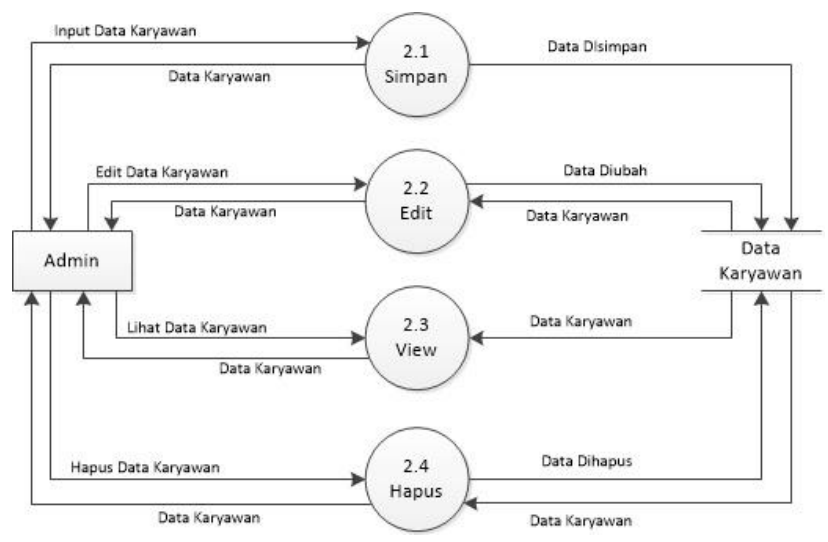

Gambar 4 DFD Level 2 Proses 2

Pada Gambar 4 di atas adalah detail dari proses pengolahan data karyawan, admin melakukan pengolahan data yaitu dengan proses-proses yang di perlukan sistem seperti proses simpan, edit, view, dan hapus yang kemudian data tersebut akan di simpan pada sebuah tabel di database yang diberi nama Karyawan dan sistem ini digunakan oleh admin.

\section{DFD Level 2 Proses 3}

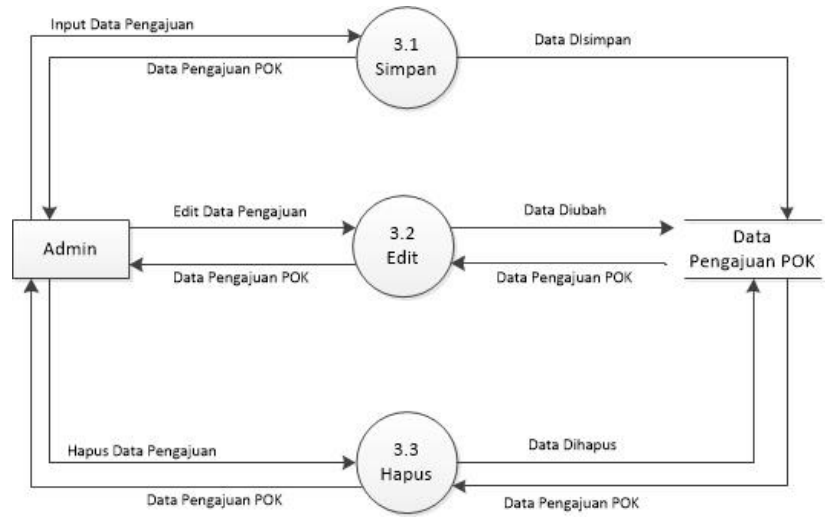

Gambar 5 DFD Level 2 Proses 3

Pada Gambar 5 di atas adalah detail dari proses pengolahan master data pengajuan POK, admin melakukan pengolahan data yaitu dengan proses-proses yang di perlukan sistem seperti proses simpan, edit, dan hapus yang kemudian data tersebut akan di simpan pada sebuah tabel di database yang diberi nama Pengajuan POK dan sistem ini digunakan oleh admin.

\section{DFD Level 2 Proses 4}

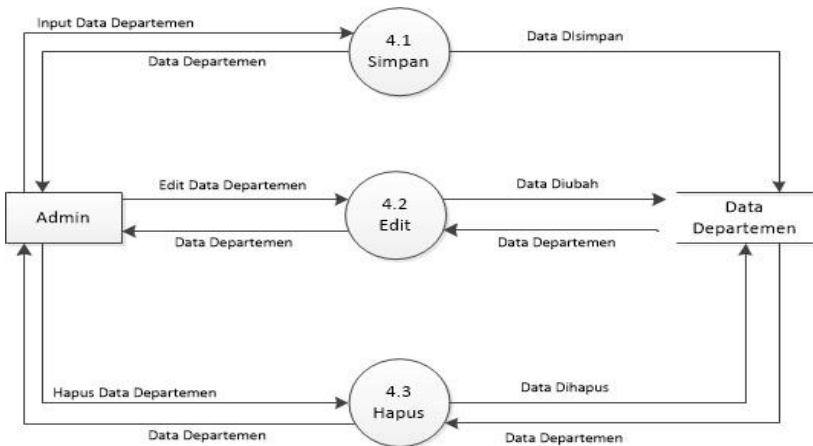

Gambar 6 DFD Level 2 Proses 4
Pada Gambar 6 di atas adalah detail dari proses pengolahan master data departemen, admin melakukan pengolahan data yaitu dengan proses-proses yang di perlukan sistem seperti proses simpan, edit, dan hapus yang kemudian data tersebut akan di simpan pada sebuah tabel di database yang diberi nama Departemen dan sistem ini digunakan oleh admin.

\section{DFD Level 2 Proses 5}

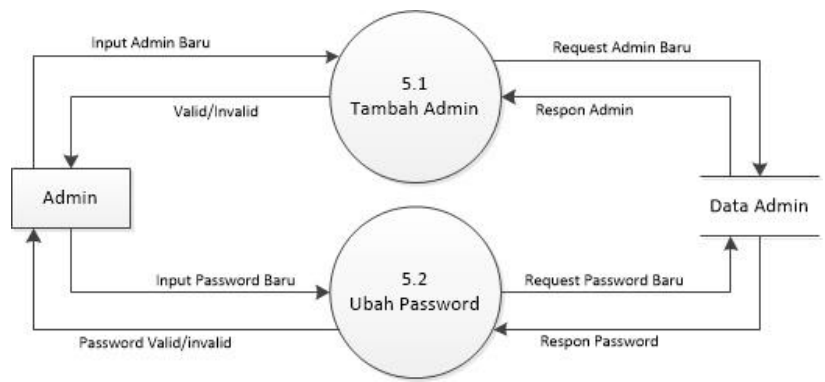

Gambar 7 DFD Level 2 Proses 5

Pada Gambar 7 di atas adalah detail dari pengelolaan admin untuk mengubah password admin yang lama dengan yang baru, kemudian data tersebut disimpan pada database Admin.

\section{ERD (Entity Relationship Diagram)}

ERD (Entity Relationship Diagram) digunakan untuk memodelkan struktur data dan hubungan antar data. Pada database Perancangan Aplikasi POK (Permintaan Order Kerja) inilah struktur data dan hubungan antar datanya. Dari uraian di atas tentang perancangan DFD dapat dibuat sebuah ERD sebagai berikut:

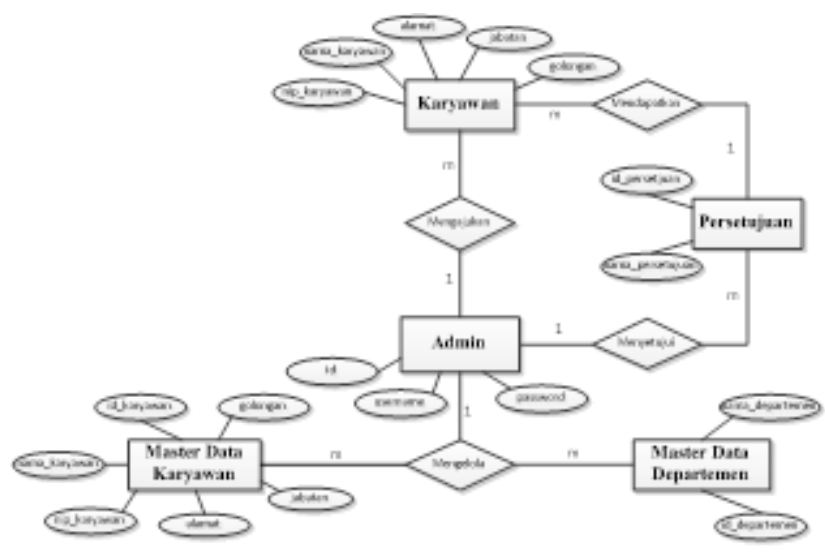

Gambar 8 Entity Relationship Diagram

Perhitungan Pada Gambar 8 merupakan ERD yang menjelaskan tentan :

a. Hubungan antara Karyawan dengan Admin adalah One to Many yaitu Karyawan hanya mengajukan ke satu Admin, sedangkan Admin menerima ajuan dari banyak Karyawan.

b. Hubungan antara Admin dengan Persetujuan adalah One to Many yaitu Admin menyetujui banyak Persetujuan, dan Persetujuan disetujui satu Admin. 
c. Hubungan antara Karyawan dengan Persetujuan adalah One to Many yaitu Karyawan hanya memiliki satu Persetujuan, sedangkan Persetujuan dimiliki banyak Karyawan.

d. Hubungan antara Admin dengan Master Data Karyawan adalah One to Many yaitu Admin mengelola banyak Master Data Karyawan, sedangkan Master Data Karyawan dikekola oleh satu Admin.

e. Hubungan antara Admin dengan Master Data Departemen adalah One to Many yaitu Admin mengelola banyak Master Data Departemen, sedangkan Master Data Departemen dikelola oleh satu Admin.

\section{HASIL DAN PEMBAHASAN}

Hasil dan pembahasan yang disajikan dalam bentuk gambar yang dibuat dengan Framework CodeIgniter, Bootstrap, dan MySQL sebagai database.

\section{Halaman Utama}

Pada halaman ini menampilkan nama Aplikasi POK dan nama Perusahaan serta menu About yang berisi informasi tentang sejarah perusahaan dan menu Login untuk masuk ke aplikasi.

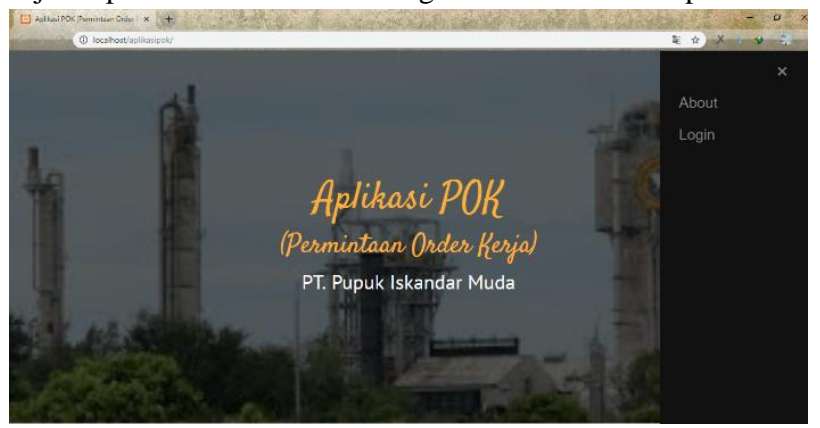

Gambar 9 Halaman Home Web Aplikasi POK

\section{Menu About}

Halaman ini menampilkan sejarah PT. Pupuk Iskandar Muda, Visi dan Misi PT. Pupuk Iskandar Muda.

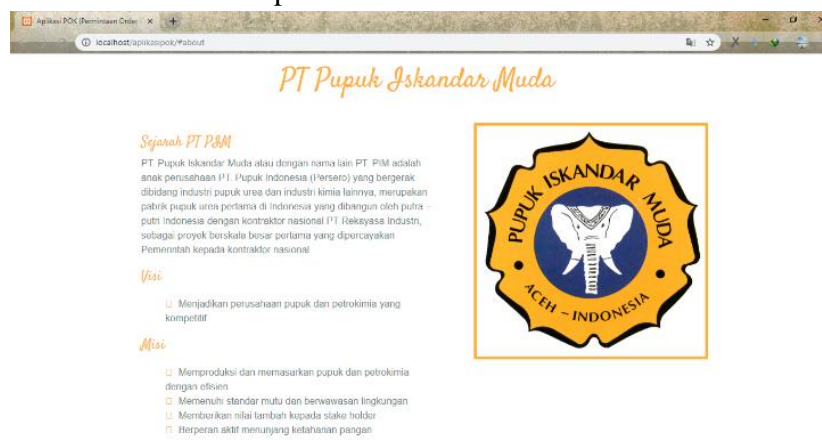

Gambar 10 Halaman About Web Aplikasi POK

\section{Menu Login}

Halaman ini menyediakan form login bagi pengguna atau admin dengan memasukkan username dan password yang telah didaftarkan pada aplikasi untuk bisa melanjutkan ke proses pelaporan kerusakan alat.

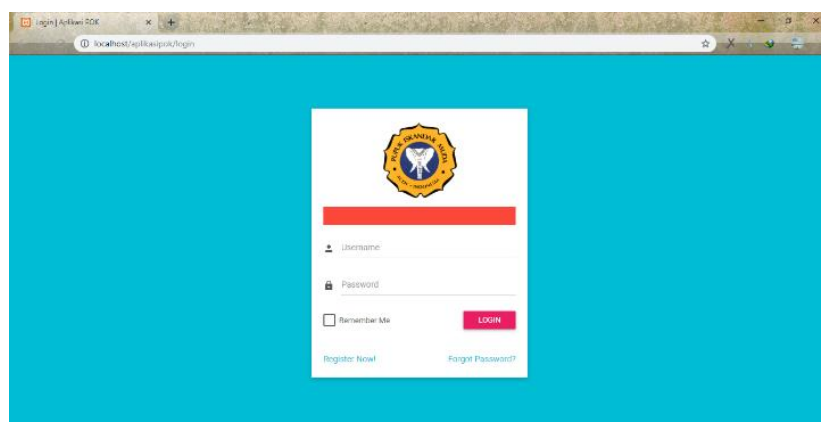

Gambar 11 Halaman Login Web Aplikasi POK

\section{Halaman User}

Halaman ini menampilkan nama User/Admin yang telah login, menu Home, menu POK, menu Master Data, menu Report, dan diagram batang dari jumlah karyawan.

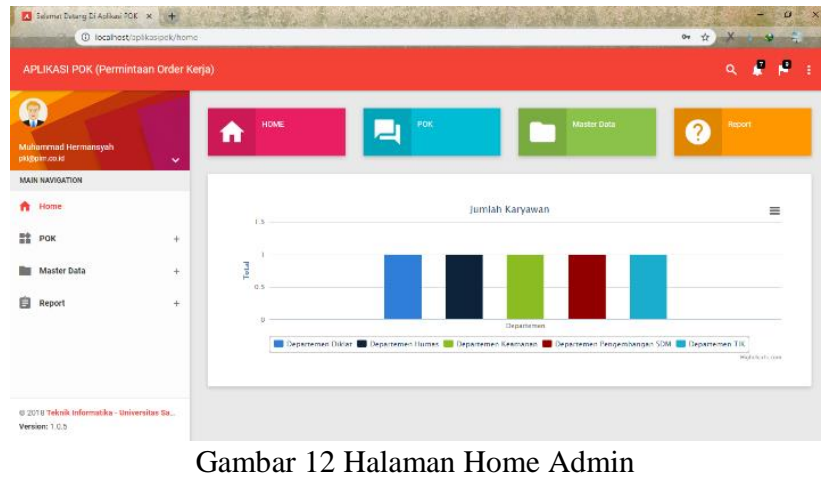

\section{Daftar POK}

Halaman ini menampilkan nama user/karyawan yang telah melakukan pengajuan kerusakan alat. Terdapat beberapa kolom dalam Daftar POK yaitu Tanggal Pengajuan, NIP Karyawan, Nama Karyawan, Departeman, Judul, dan Deskripsi.

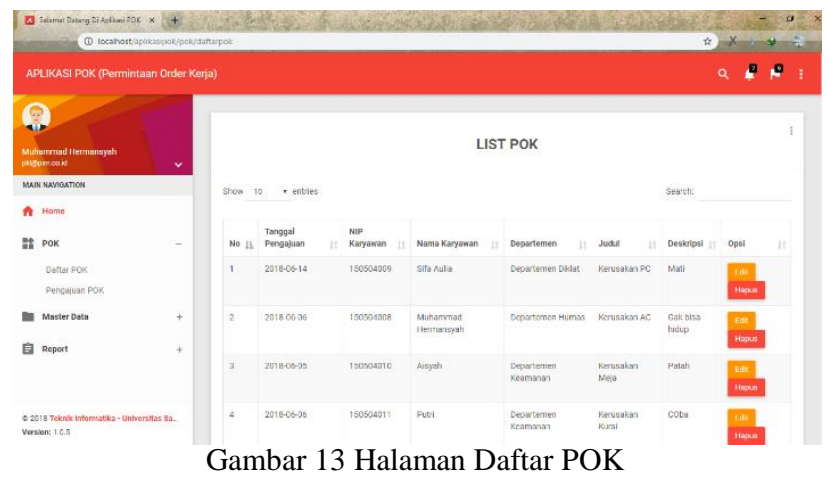

\section{Form Pengajuan POK}

Halaman ini menampilkan form untuk melakukan pengajuan. User dapat memasukkan keluhan yang terjadi pada kerusakan alat. Terdapat kolom yang harus diisi yaitu Tanggal Pengajuan, NIP Karyawan, Nama Karyawan, Departeman, Judul, dan Deskripsi kerusakan alat. 


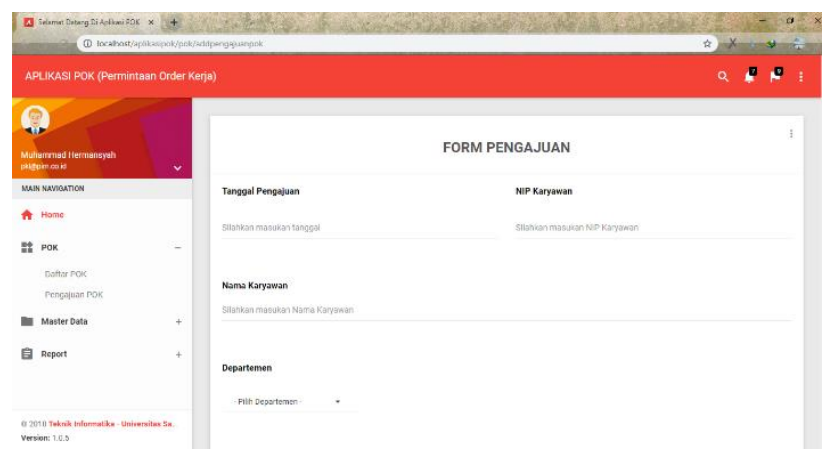

Gambar 14 Halaman Form Pengajuan POK

\section{Master Data Karyawan}

Halaman ini menampilkan seluruh data karyawan yang ada pada PT. Pupuk Iskandar Muda. Terdapat kolom Nama Karyawan, NIP Karyawan, Golongan, Jabatan, dan Alamat.

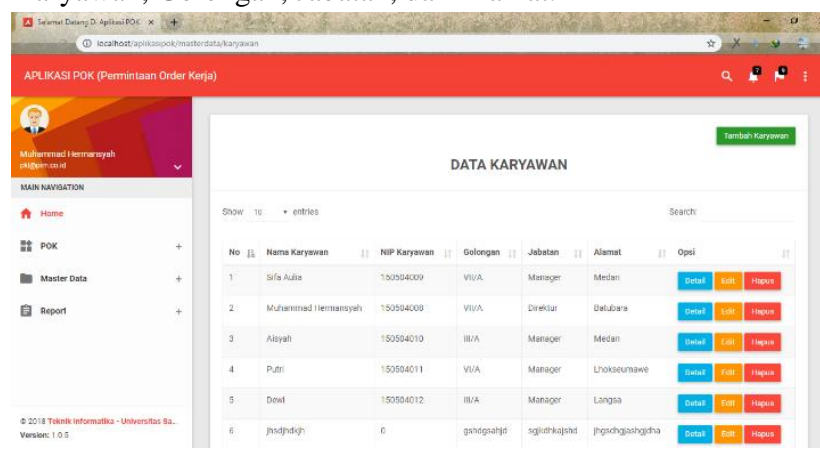

Gambar 15 Halaman Master Data Karyawan

\section{Master Data Departemen}

Halaman ini menampilkan seluruh data departemen yang ada pada PT. Pupuk Iskandar Muda. Terdapat kolom Nomor dan Nama Departemen.

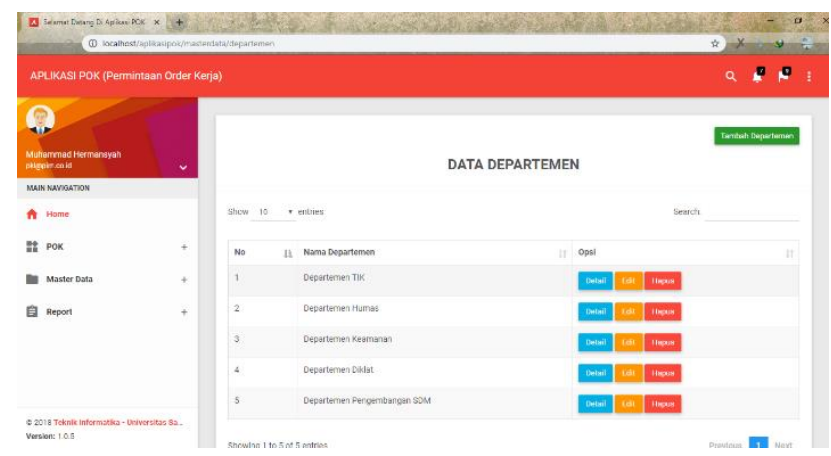

Gambar 16 Halaman Master Data Departemen

\section{Report POK}

Halaman ini menampilkan seluruh laporan pengajuan kerusakan alat yang ada pada PT. Pupuk Iskandar Muda.

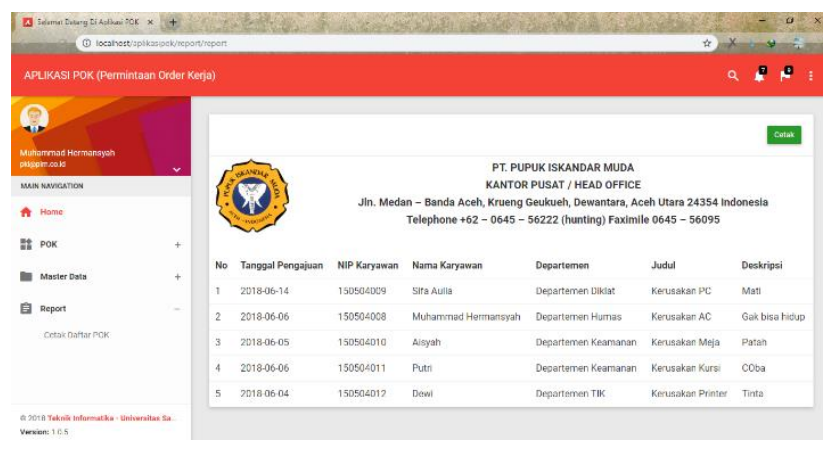

Gambar 17 Halaman Report POK

\section{Cetak Daftar POK}

Halaman ini berguna untuk mencetak laporan kerusakan alat pada PT. Pupuk Iskandar Muda.

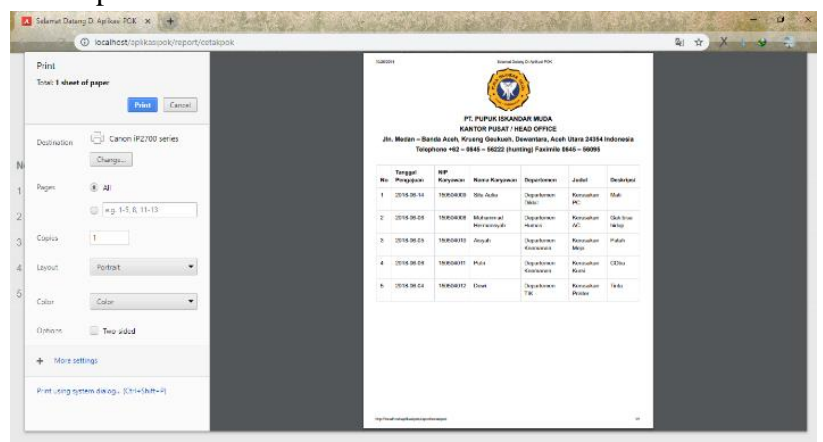

Gambar 18 Halaman Cetak Daftar POK

\section{KESIMPULAN DAN SARAN}

Hasil dari perancangan dan implementasi pembahasan sebelumnya maka dapat disimpulkan antara lain:

1. 1Sistem permintaan order kerja pada PT. Pupuk Iskandar Muda masih menggunakan proses yang manual, sehingga sering terdapat permasalahanpermasalahan dalam kegiatan operasionalnya.

2. Adanya aplikasi ini, proses permintaan order kerja tidak lagi dilakukan secara manual melainkan dengan menggunakan aplikasi berbasis web.

3. Pembuatan Aplikasi Permintaan Order Kerja (POK) pada PT. Pupuk Iskandar Muda ini dibangun menggunakan Framework CodeIgniter dan Bootstrap sehingga memiliki pengkodean program yang lebih terstruktur dan tampilan yang lebih menarik.

4. Semua karyawan yang ada pada PT. Pupuk Iskandar Muda dapat dengan mudah melaporkan masalah kerusakan alat yang ada pada suatu departemen dan karyawan dapat mengetahui bahwa alat tersebut sudah selesai diperbaiki tanpa harus menanyakan langsung kepada teknisi ataupun pihak lain.

5. Adanya aplikasi ini, jika pihak kantor departemen membutuhkan berkas berupa data kerusakan alat yang telah diperbaiki, maka dengan mudah dapat didapatkan melalui aplikasi. 


\section{DAFTAR PUSTAKA}

[1] Alatas, Husein. 2013. Responsive Web Design dengan PHP \& Bootstrap. Yogyakarta : Lokomedia.

[2] Basuki, AP. 2010. Membangun Web Berbasis PHP dengan Framework CodeIgniter. Yogyakarta : Lokomedia.

[3] Jogiyanto, HM. 2005. Analisis dan Desain Sistem Informasi, ANDI. Yogyakarta.

[4] Kadir, Abdul. 2003. Pengenalan Sistem Informasi. ANDI. Yogyakarta.

[5] Nugroho, Bunafit. 2004. PHP dan MySQL Dengan Editor Dreamweaver MX. Andi. Yogyakarta.

[6] Nugroho, A. 2011. Perancangan dan Implementasi Sistem Basis Data. Andi Publisher. Yogyakarta.

[7] Susanto, Azhar. 2004. Sistem Informasi Manajemen Konsep dan Pengembangannya. Lingga Jaya, Bandung.

[8] Yana, Tulus. 2012. Membangun WEB Interaktif dengan Adobe Dreamweaver CS5.5, PHP \& MySQL. Yogyakarta: CV Andi Offset. 